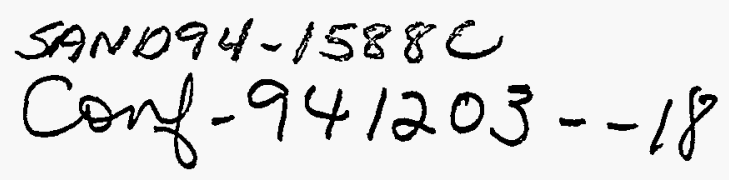

\title{
HIGH-EFFICIENCY SOLAR CELLS USING HEM SILICON
}

\author{
C. P. Khaltak', F. Schmid', and W. K. Schubert \\ 'Crystal Syslems, Inc, 27 Congress Stroel, Salem, MA 01970-5597, USA \\ ${ }^{2}$ Sandia National Laboratories, Albuquerque, NM 87185-0752, USA
}

\begin{abstract}
Developments in Heat Exchanger Method (HEM) technology for produetion of multicrystalline silicon ingot produclion have led to growth of larger ingots $(55 \mathrm{~cm}$ square cross section) with lower costs and reliability in production. A single reusable crucible has been used to produce 16 multicrystalline $33 \mathrm{~cm}$ square cross section 40 $\mathrm{kg}$ ingots, and capabillty to produce $44 \mathrm{~cm}$ ingots has been demonstrated. Large area solar cells of $18.3 \%\left(42 \mathrm{~cm}^{2}\right)$ and $15.3 \%\left(100 \mathrm{~cm}^{2}\right)$ efficiency have been produced without optimization of the material production and the solar cell processing.
\end{abstract}

\section{INTRODUCTION}

Multicrystalline sillicon ingol technologies [1-8] offer promise for cost-effective, high-efficiency material for photovoltaic applications. These approaches are becoming the mainstay for current production of modules for power generation. This paper reports the progress made in the Heat Exchanger Method (HEM) lechnology to increase ingot size and throughput from furnaces, improving efficiencies of solar cells, and adopting the use of reusable crucibles to achieve further cost reductions.

All processing component costs for ingol technology have been reduced. On the basis of these costs, the proportion of expendable materials costs is high and therefore getting renewed interest. Reduction of crucible costs is key to achieving economic silicon ingot production. Most ingot technologies use silica crucibles because silica is available in high purity form at relatively low cost. Raw malerial costs limit the potential for further reductions in the cost of the silica crucible itself. The crucible contribution to the lotal ingot cost could bo reduced further by increasing the ingot size. In addition, throughput can bo increased with larger ingols and energy costs reduced if the processing time can be held constant. Material quality is expected to Improve with larger ingot size due to reduced surface to volume ratio for large size. This translates to reduced cost per watt for the solar cells produced from the ingot.

2 This author's contribution was supported by the Pholovoltaic Technology Division, U.S. Department of Energy, Coniract DE-AC0494AL85000.
As mentioned above, silica crucible cost reductions may be limited by the cost of the raw materials. Furthermore, devitrification of the fused silica during ingot production prevents reuse of the crucibles. Therefore, another avenue for cost savings is the use of reusable crucibles made from other cucible materials. It is essential, in this approach, to retain purity of the silicon ingot so that solar cell efficiencies are not compromised. The feasibility of reusing crucibles was eslablished [7] previously by producing multicrystalline silicon ingots in the same crucible with the HEM process. This paper also reports progress with reusable crucibles and documents the quality of the material produced through the high performance of solar cells made from it.

\section{HEM SILICON FROM SILICA CRUCIBLES}

The HEM has been used for production [B] of $44 \mathrm{~cm}$ square cross section sllicon ingots using high purity fused silica crucibles which were heat treated prior to use to promote crucible delamination and prevent cracking of the solidified silicon ingot. It was necessary to use silica crucibles with graphite plates because the ingol solidification temperature was above the softening point of fused silica. Ingols grown in silica crucibles showed distortion and taper, and oversize ingots had to be produced to yield bars to specification.

Growth of silicon ingots was carried out by HEM under vacuum. Modifications were made to the HEM furnace and the heat exchanger system so the crucible could be lowered in the heat zone. This improved reliability in reproducible growth of the $80 \mathrm{~kg}$ charge and the feasibility of producing $100 \mathrm{~kg}$ ingots [1].

As mentioned above, the heat-treated silica crucible relied on the devitrification of the fused silica interior during growth, causing delamination of the crucible during coot down and preventing ingot cracking. It was necessary to develop a HEM cycle which was compalible with growth of silicon and for devitrification of the fused silica crucible. The reliability of the heat-treated fused silica crucible decreased as the size of the ingot was increased.

In order to decouple the ingot growth and the crucible delamination parameters, a coated silica crucible was developed for HEM sllicon ingot production. Various silicon-nitride-based coatings were applied to the inside surfaces of a slip-cast fused silica crueible. The coating 


\section{DISCLAIMER}

This report was prepared as an account of work sponsored by an agency of the United States Government. Neither the United States Government nor any agency thereof, nor any of their employees, makes any warranty, express or implied, or assumes any legal liability or responsibility for the accuracy, completeness, or usefulness of any information, apparatus, product, or process disclosed, or represents that its use would not infringe privately owned rights. Reference herein to any specific commercial product, process, or service by trade name, trademark, manufacturer, or otherwise does not necessarily constitute or imply its endorsement, recommendation, or favoring by the United States Government or any agency thereof. The views and opinions of authors expressed herein do not necessarily state or reflect those of the United States Government or any agency thereof. 


\section{DISCLAIMER}

Portions of this document may be illegible electronic image products. Images are produced from the best available original document. 
was meant to prevent attachment of the silicon ingot to the cruclble during growth, and to prevent impurities from the crucible from contaminating the silicon ingot. The siliconnitride-based coatings were not stable at the growth temperatures under vacuum; the HEM processing was, therefore, carried out under inart gas atmosphere to avoid decomposition of the coating.

Multicrystalline sillicon ingots weighing $90 \mathrm{~kg}$ with $44 \mathrm{~cm}$ square cross-section were grown using this approach. This ingot was geometrically square with flat sides, and controlled growth was achieved in the comers. Characterization showed that all the characteristics of HEM silicon produced in heat treated silica crucibles were retained and that the production of high performance solar cells was not compromised. A mapping of the resistivity of a slab sectioned parallel to one of the square sides shows that extremely good uniformity of electrical properties was achieved (see Fig. 1).

(TOP)

.4 .4 .6 .7 .6 .4 .3 .4 .4 .5 .5 .5 .4

.7 .6 .6 .6 .7 .7 .7 .6 .5 .5 .5 .5

.7 .6 .6 .7 .7 .7 .7 .7 .6 .7 .6 .7

.8 .7 .6 .7 .6 .7 .6 .7 .7 .7 .7 .7 .7

.8 .8 .8 .7 .8 .8 .8 .7 .8 .9 .8 .8 .8

.8 .8 .8 .7 .8 .7 .9 .8 .8 .8 .8 .7

.8 .8 .8 .7 .8 .7 .8 .9 .8 .9 .7 .8

.9 .8 .9 .9 .8 .8 .8 .8 .8 .7 .8 .8 .8

.8 .8 .9 .9 .8 .9 .9 .8 .9 .8 .7 .9 (Boltom)

Fig. 1. Cross section of a $44 \mathrm{~cm}$ ingot and mapping of resistivity (in ohm-cm) showing uniformity in structure and electrical properties.

Fig. 2. A $55 \mathrm{~cm}$ square cross section multicystalline silicon ingot grown by HEM showing controlled growth.
The reliability of the coated crucible, and decoupling of the HEM processing cycle for ingol solidification and cruclble delamination, allowed increase in the size of the ingols. Figure 2 shows $55 \mathrm{~cm}$ square cross section multicrystalline silicon ingot grown by HEM in a sillica crucible. All the desirable characteristics of controlled growth were retained as the ingot size was increased. Controlled growth is confirmed because the last material to solidify is very close to the comers; this material is identified by the tip of silicon in the four comers due to expansion of the last silicon solidified.

\section{HEM SILICON FROM REUSABLE CRUCIBLES}

The essentjal requirements of a reusable crucible for directional growth of multicystalline silicon ingols are:

a) compatibility with sillcon ingot growth to prevent ingot or crucible cracking,

b) a crucible material which is stable at the processing temperature for directional growh,

c) feasibility to coat to prevent altachment of silicon,

d) non-contamination of the silicon which reduces solar cell performance,

e) a softening temperature higher than the growth temperature,

i) fabrication in large sizes and dosired square shapes achievable at low cost, and

g) crucible reusable multiple times to reduce cost.

Based upon these requirements, a high temperature nonoxide ceramic crucible was selected and reported on [7]. Such a crucible was used to produce several $40 \mathrm{~kg}, 33 \mathrm{~cm}$ square cross-section ingots without degradation of the silicon or the crucible. Characterization of the silicon showed vertically oriented grain boundaries, uniformity in resistivity, low disiocation density, diffusion lengths up to $270 \mathrm{\mu m}$, and less than 1 ppma oxygen concentration. Solar cells of $2 \mathrm{~cm} \times 2 \mathrm{~cm}$ size showed efficiencies over $15 \%[7]$.

The reusable crucibles were manufaclured with a square cross section and a slight taper to the side walls to aid removal of the ingol after growth. A silicon-nitride-based coating was applied to the inside surfaces of these crucibles. Ingol growth was carried out by HEM using processing parameters similar to those developed for a coated silica crucible. The developmental effort was carried out at $40 \mathrm{~kg}, 33 \mathrm{~cm}$ square cross-section ingot size, and a single crucible was used to produce 16 ingots. Characterization of the ingots showed the performance of the material remained consistent with the number of times the crucible was used.

In addition to reduced crucible cosis for the production of multicrystalline silicon ingots, the material utilization was also improved. This was achieved because the high temperature ceramic crucible material did not show distorion after ingol growth; therefore, ingols could be produced closer to finished size to improve ingol utilization. These ingots were of reproducible size, and only the lapered side walls and the bottom and top surfaces of the 
Ingot had to be removed; the rest of the material could be slicad for solar cells.

Mullierystalline silicon grown in reusable crucibles showed less than 1 ppma oxygen concentration [9]. This concentration is much lower than silicon solidified in silica crucibles [10]. Oxygen contamination is due to reaction of molten silicon with the silica cruciblo [11]; a non-oxide, ceramic crucible, therefore, does not cause contamination of sillicon from oxygen.

Once the reliability of the reusable crieibles was demonstrated, the crucible size was increased to $44 \mathrm{~cm}$ square cross-section. Silicon ingols weighing $65 \mathrm{~kg}$ were directionally grown by HEM. The height of these ingots was less than produced in sillca crucibles because the reusable crucibles were shorter. Characterization of multicrystalline silicon ingots produced in reusable crucibles showed that the quality of silicon was not compromised and was of performance similar to silicon producied in silica crucibles.

\section{SOLAR CELLL PERFORMANCE}

Several ingots produced in fused silica and reusable crucibles were sectioned to approximately $10 \mathrm{~cm} \times 10 \mathrm{~cm}$ cross section bars. Large size grains $(1.2 \mathrm{~cm})$ with vertically oriented grain boundaries were produced. Resistivity of the silicon was consistent with doping and segregation effects.

Wafers were processed to characterize both lateral uniformity and uniformity along the growth direction. An array of $2 \mathrm{~cm} \times 2 \mathrm{~cm}$ cells was produced on $10 \mathrm{~cm} \times 10$ $\mathrm{cm}$ wafers taken from the top, middle and bottom of ingots. Average wafer efficiencies (B cells/slica) of $15.8 \%$ were achieved during initial characterization of the material on wafers taken from the middle of an ingot.

The best efficiency of individual cells produced in either a reusable or a coated silica crucible, using the same processing lechniques, is shown in Table 1 . While the solar cell efficiencies are the same, slight differences in performance parameters can be explaineo by dififerences in resistivity and lower oxygen concentration for silicon grown in a reusable crucible. This data shows that the quality of silicen grown by HEM using the two types of crucibles is quite similar.

Table 1. Periormance of Solar Cells $(2 \mathrm{~cm} \times 2 \mathrm{~cm})$ during Initial ovaluation of HEM silicon produced using different cruábles.

\begin{tabular}{|c|c|c|c|c|}
\hline Crucible & $\begin{array}{l}V_{\infty} \\
M\end{array}$ & 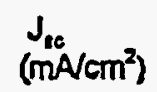 & $\begin{array}{l}F F \\
(\%)\end{array}$ & $\begin{array}{l}\text { Eff. } \\
\text { (\%) }\end{array}$ \\
\hline $\begin{array}{l}\text { Sillca } \\
\text { Reusable }\end{array}$ & $\begin{array}{l}0.616 \\
0.623\end{array}$ & $\begin{array}{l}34.00 \\
33.23\end{array}$ & $\begin{array}{l}79.2 \\
80.1\end{array}$ & $\begin{array}{l}16.6 \\
16.6\end{array}$ \\
\hline
\end{tabular}

Data for variation in solar cell performance as a function of posilion in the ingol showed that the highest elficiency for HEM silicon corresponds to the middle section of the bar with a slight deterioration in performance near the top of the ingot and bottom of the ingol. Slight deterioration at the bottom of the ingot may be due to thermal stress because this material undergoes maximum thermal gradient during ingot growth. The degradation in performance near the top of the ingot may be due to segregation of impurities during growlh.

HEM sillicon was processed into high performance solar cells at the University Center of Excellence for Photovoltaics and Edueation, Georgia institute of Technology, and solar cells of $17.4 \%$ efficiency were produced $\left(1 \mathrm{~cm}^{2}\right)$ using this approach [12]. The characteristics of this solar cell were confirmed at National Renewable Energy Laboratory (NREL).

\section{LARGE AREA SOLAR CELL FABRICATION}

Based upon characterization data of HEM silicon, Sandla National Laboratories produced high performance modules with this material. The target for the module was module efficiency in excess of $15 \%$ using solar cells of $42 \mathrm{~cm}^{2}$ area. The first batch of 12 cells (41.98 $\mathrm{cm}^{2}$ area) yielded an average efficiency of $18.0 \pm 0.2 \%$ with a range of values between 15.6 and $18.3 \%$ (Table 11). For this effort 72 cells were fabrieated, and 88 were completed; thres of these cells broke during processing, and one broke during testing. The cells ranged in efficiency from 15.0 to $18.3 \%$ with an average value of $15.6 \%$ [13]. Two modules were fabricated, and the module efficiencies wero over $15 \%$ under standard test conditions [14].

Table Il. Characleristics of one batch of $42 \mathrm{~cm}^{2}$ solar cells produced using HEM multierystalline silicon.

\begin{tabular}{|c|c|c|c|c|}
\hline Wafer & $\begin{array}{l}V_{\infty} \\
M\end{array}$ & $\begin{array}{l}J_{k e} \\
\left(m A c m^{2}\right)\end{array}$ & $\begin{array}{l}F F \\
(\%)\end{array}$ & $\begin{array}{l}\text { Eff } \\
(\%)\end{array}$ \\
\hline $\begin{array}{c}1 \\
2 \\
3 \\
4 \\
5 \\
6 \\
8 \\
9 \\
10 \\
11 . \\
12 \\
13\end{array}$. & $\begin{array}{l}0.608 \\
0.609 \\
0.608 \\
0.607 \\
0.608 \\
0.605 \\
0.609 \\
0.605 \\
0.603 \\
0.605 \\
0.609 \\
0.603\end{array}$ & $\begin{array}{l}33.83 \\
33.80 \\
33.66 \\
34.14 \\
33.90 \\
33.40 \\
33.83 \\
33.47 \\
33.11 \\
33.30 \\
33.73 \\
33.40\end{array}$ & $\begin{array}{l}79.2 \\
79.2 \\
78.8 \\
77.6 \\
79.0 \\
78.1 \\
78.5 \\
77.9 \\
78.0 \\
79.1 \\
78.3 \\
78.7\end{array}$ & $\begin{array}{l}16.3 \\
16.3 \\
16.1 \\
16.1 \\
16.3 \\
15.8 \\
16.2 \\
15.8 \\
15.6 \\
15.9 \\
16.1 \\
15.8\end{array}$ \\
\hline $\begin{array}{l}\text { Mean } \\
\text { s.d. }\end{array}$ & $\begin{array}{l}0.607 \\
0.002\end{array}$ & $\begin{array}{r}33.63 \\
0.29\end{array}$ & $\begin{array}{r}78.5 \\
0.5\end{array}$ & $\begin{array}{r}16.0 \\
0.2\end{array}$ \\
\hline
\end{tabular}

During a recent experiment at ASE Americas, a number of different solar grade based materials were processed through the high throughput production line to compare 
performance with that of EFG material. This production line was oplimized for EFO malerial and combines a number of process steps to improve substrale quality. It incorporates high throughput production features; upgrading is entirely in the process and does not affect its throughput or costs.

The diffusion and phosphorous gettering oceurs in a high throughput beft furnace process [15]. Antireflection coating is combined with passivation [16]. A full area aluminum back contact is used and regrown at $850^{\circ} \mathrm{C}$ to provide both gettering and a back surface field $[17,18]$ and a front silver metallization is applied that is fired through a silicon nitride coat to complete the process $[19,20]$. All these steps are integraled in a line with a throughput of approximately 700 cellshour $(10 \mathrm{~cm} \times 10 \mathrm{~cm})$. The data of a batch of 21 cells processed from HEM sillicon is shown in Table III (cell measurements were done at ASE Americas). These results were achieved without optimization of HEM silicon processing or tailoring the cell process to the material. This data (Table III) shows an average cell efficiency of $14.13 \%$ with a maximum value of $15.3 \%$.

Table III. Performance of $100 \mathrm{~cm}^{2}$ solar cells produced by ASE Americas using HEM multierystalline silicon.

\begin{tabular}{|c|c|c|c|c|}
\hline Cell & $\begin{array}{l}V_{\infty} \\
M\end{array}$ & $\begin{array}{l}J_{s o} \\
\left(m A C m^{2}\right)\end{array}$ & $\begin{array}{l}F F \\
(\%)\end{array}$ & $\begin{array}{l}\text { Eff } \\
(\%)\end{array}$ \\
\hline $\begin{array}{c}1 \\
2 \\
3 \\
4 \\
5 \\
8 \\
7 \\
8 \\
9 \\
10 \\
11 \\
12 \\
13 \\
14 \\
15 \\
16 \\
17 \\
18 \\
19 \\
20 \\
21\end{array}$ & $\begin{array}{l}0.6019 \\
0.5844 \\
0.6094 \\
0.5937 \\
0.6156 \\
0.5983 \\
0.6160 \\
0.6129 \\
0.6136 \\
0.6035 \\
0.6158 \\
0.6158 \\
0.6143 \\
0.6102 \\
0.5992 \\
0.6119 \\
0.6140 \\
0.6130 \\
0.6160 \\
0.5991 \\
0.6102\end{array}$ & $\begin{array}{l}30.29 \\
28.84 \\
31.11 \\
29.15 \\
32.31 \\
28.81 \\
32.12 \\
31.75 \\
31.81 \\
30.10 \\
32.33 \\
32.22 \\
32.08 \\
31.48 \\
29.79 \\
31.71 \\
32.22 \\
31.52 \\
32.27 \\
29.46 \\
31.12\end{array}$ & $\begin{array}{l}72.88 \\
73.38 \\
74.99 \\
73.97 \\
74.90 \\
73.03 \\
75.89 \\
74.50 \\
74.58 \\
75.49 \\
76.08 \\
77.09 \\
76.35 \\
72.97 \\
73.49 \\
75.73 \\
72.88 \\
74.78 \\
75.36 \\
74.01 \\
75.30\end{array}$ & $\begin{array}{l}13.29 \\
12.57 \\
14.22 \\
12.88 \\
14.90 \\
12.55 \\
15.02 \\
14.50 \\
14.58 \\
13.71 \\
15.15 \\
15.29 \\
15.05 \\
14.02 \\
13.10 \\
14.70 \\
14.42 \\
14.45 \\
14.98 \\
13.05 \\
14.30\end{array}$ \\
\hline $\begin{array}{l}\text { Mean } \\
\text { s.d. }\end{array}$ & $\begin{array}{l}0.608 \\
0.008\end{array}$ & $\begin{array}{c}31.07 \\
1.24\end{array}$ & $\begin{array}{r}74.64 \\
1.24\end{array}$ & $\begin{array}{r}14.13 \\
0.89\end{array}$ \\
\hline
\end{tabular}

\section{CONCLUSIONS}

Two independent approaches have been developed to reduce the crucible cost contribution for multierystalline allicon ingot production by HEM. A coated silica crucible has been used for improved cross-section, $80 \mathrm{~kg}$ silicon ingots. Growth of silicon ingols in reusable crucibles has also been extended $1044 \mathrm{~cm}$ square cross-section size and 16 ingots have been produced using one crucible.

Solar cells fabricated from multicrystalline silicon produced in silica or reusable crucibles have shown high performance with minor variations. Efficiencies of $17.4 \%$ $\left(1 \mathrm{~cm}^{2}\right), 16.3 \%\left(42 \mathrm{~cm}^{2}\right)$ and $15.3 \%\left(100 \mathrm{~cm}^{2}\right)$ have been demonstrated. Over $15 \%$ officiency modules have been fabricated using HEM multicrystalline sillicon.

Larger ingol growth and high performance of HEM silicon will allow major cost reduction of solar cell production. Controlled growth of $55 \mathrm{~cm}$ square ingots will achieve economies near ferm and the impact of reusable crucibles will be beneficial for the future.

\section{REFERENCES}

[1] C. P. Khattak, F. Schmid, D. W. Cunningham and J. G. Summers, "Directional Solidification of $80 \mathrm{~kg}$ Multicrystalline Silicon Ingols by HEM", Twenty-Second IEEE PVSC, 1991, pP.878-978.

[2] D. Helmreich, "The Wacker Ingot Casting Process" in: Silicon Processing for Photovoltaics $\|_{3}$ eds. C. P. Khattak and K. V. Ravi (North Holland, Amsterdam, 1987) pp.97151.

[3] W. F. Regnault and K. C. Yoo, "Lifetime Enhancement in Semisystalline Silicon by Struetural Defeel Density Reduction", Seventesnth IEEE PVSC, 1984, pp.286-291.

[4] J. Fally and C. Guenel, "Study of the Elaboration of Semierystalline Silicon Ingots", Third E. C. PSEC, 1980. pp.588-602.

[5] 1. A. Dorrily, B. J. Garrard and D. A. Hukin, "Polycrystalline Photovoltaic Silicon Ingot Production". Tenth E. C. PSEC, 1991, pp.317-318.

[G] W. Koch, W. Krumbe, H. Lange, W. Schmidt, F. Schomann and G. Wahl, "Development of Cost Effective Silicon Material- and Cell-Fabrication-Processes for High Efficient Large Area Terrestrial Solar Cells", Twelfth E. C. PSEC, 1994, pp.797.798.

[7] C. P. Khattak, F. Schmid, W. K. Schubert, M. Cudzinovic and B. L. Sopori, "Characteristics of HEM Silicon Produced in a Reusable Crucible", Twenty-third IEEE PVSC, 1983. pp. 73.77.

[8] C. P. Khattak and F. Schmid, "HEM Technology for Photovoltaic Applications", PVSEC-6, Pp.117-124. 
[9] C. P. Khatiak, F. Schmid, M. Cudzinovic and B. L. Sopori, "Impurity Defect Analysis of HEM Sllicon", Third Workshop on the Role of Point Defects and Defect Complexes in Silicon Device Processing, 1893, pp.13-18.

[10] K. A. Dumas, C. P. Khattak and F. Schmid, "Characteristics of HEM Silicon for Solar Cells", Fifteenth IEEE PVSC, 1981, pp.954-958.

[11] F. Schmid, C. P. Khattak, T. G. Digges, Jr. and L. Kaufiman, "Origin of SiC Impurities in Silicon Crystals Grown from the Melt in Vacuum", d. Electrochem. Soc. 126, 1978, pp.935-938.

[12] A. Rohatol, Georgia Institute of Technology, personal communication.

[13] W. K. Schubert, D. S. Ruby, P.A. Basore. J. M. Geo, M. E. Buck, and H. L. Tardy, "A Simple Single Photomask Process for Fabrication of High-Efficiency Multicrystalline Silicon Solar Cells", This conference.

[14] D. L. King, W. K. Schubert and T. D. Hund, "World's First 15\%-Eficient Multicrystalline Silicon Modules", This Conference.

[15] M. D. Rosenblum and J. I. Hanoka, U. S. Patent $5,270,248$.

[16] A. R. Chaudhuri and K. V. Ravi, U. K. Patent GB 2215 $129 \mathrm{~B}$.

[17] F. J. Bottari, J. I. Hanoka, and F. W. Sylva, U. S. Patent 5,151,386.

[18] J. A. Amick, F. J. Bottari and J. I. Hanoka, J. Electrochem. Soc. (to be published).

[19] J. I. Hanoka and S. E. Danielson, U. S. Patent $5,151,377$.

[20] J. I. Hanoka, Censdian Patent 1,323,452. 